\title{
WHAT HAPPENED TO AESTHETICS AND ART OVER THE LAST 100 YEARS? CONTRADICTIONS AND ANTAGONISMS - THEORY WARS!
}

\author{
A B S S T R A C T
}

The subject of my paper is the dynamic and transformational relations between aesthetics and art from 1919 to 2019. The first problem to be discussed will be the relationship between art and politics at the Bauhaus and art institutes of the Soviet avant-garde. Next, I will point to differences in Marxist concepts of socialist realism and critical theory on modern culture and art. I will analyse the relationship between the concept of the autonomy of art, especially painting and minimal art. A comparison will be derived between anti-art (Dada, Neo-Dada) and anti-philosophy (Friedrich Nietzsche, Ludwig Wittgenstein, Jacques Lacan). I will highlight approaches from analytical meta-aesthetics to the interpretation of Duchamp's readymade, deriving a theory of art in conceptual art. Special attention will be paid to the "theoretical conflicts" between phenomenology and structuralism, as well as poststructuralism. I will conclude my discussion by identifying the "aesthetic condition" in relation to "contemporary art" (feminist, activist, political, ecological, participatory, and appropriative art).

The aim of my discussion will be to highlight the character of modern and contemporary aesthetics in relation to art theory, by way of diagrammatic reflection on the binaries, differences, and reconstructions of dialectics.

\section{Miško Šuvaković}

Faculty of Media and Communication - Singidunum University

ART SCHOOLS

MARXISM

CRITICAL THEORY

ANALYTICAL AESTHETICS

ART HISTORY

PHENOMENOLOGY

STRUCTURALISM

POSTSTRUCTURALISM 
The subject of my paper is the dynamic and transformational "processings" that have occurred in aesthetics and art between 1919 and 2019. This concerns the relations between aesthetics, art, culture, society, and, the world. If the subject is "processings", then my paper will be about the "politics of aesthetics" in relation to aesthetics as a discipline and in relation to other domains that are referential to it. My paper is comparative and based on diagrammatic indexing and mapping of the relations between art and aesthetics in the field of sociality. Diagrammatic indexing and mapping of, first and foremost, the relations between art and aesthetics is a matter of the "politics of aesthetics" and a matter of the "politics of art": "The diagram is no longer an auditory or visual archive but a map, a cartography that is coextensive with the whole social field. It is an abstract machine'. ${ }^{1}$

I set out from the angle that the unique concept of aesthetics as a philosophical science began growing in complexity from its very inception and led toward distinguishing between the respective characters of philosophical "knowledge" pertaining to the beautiful (Baumgarten), the sensuous (Kant), the artistic (Hegel), and the political (Schiller).

The crisis of philosophy began no doubt in the "century of philosophy". It began with Marx's diagnosis of 'the poverty of philosophy' in a world beset by real human poverty amid the industrial society of exploitation. It also began with Friedrich Nietzsche, with his 'grandiose', immanently philosophical failure to derive yet another great totalising philosophical system of thinking about everything and for everything. This was the first time that the notion of a philosophical failure became the cornerstone of a reordering of philosophy, a reordering that would grow significant, above all, in the twentieth century. Finally, it also began when Dr Sigmund Freud postulated his theory of the unconscious as a universal discourse about the "un-whole subject" and fragile subjectivity within human life, a humanist discourse that "moved across" the empirical and pseudo-empirical fields of biomedical and socio-cultural hypotheses outside of the professional security of philosophical paradigms and styles. Interpreting this in retrospect, one might say that Marx, Nietzsche, and Freud undermined the certainty of philosophical comprehension and thus destabilised the field of a potential aesthetic theory. This philosophical crisis of aesthetics was manifested in various initiatives, for instance, to abandon philosophical aesthetics in favour of a scientific aesthetics, i.e. to posit aesthetics as the science of form (Konrad Fiedler, Clive Bell), science or naturalised science of the arts (Max Dessoir), science of technology in art (Max Bense), and, finally, as a crisis of metaphysics in general (Martin Heidegger). One of the final attempts to defend philosophical 
aesthetics was the following dictum of the philosopher Nicolai Hartmann, issued in the introduction to his seminal work Aesthetics (1953): 'One writes aesthetics neither for the creator nor for the patron of the arts, but exclusively for the thinker, for whom the doings and the attitudes of both have become a puzzle'.2

Roughly speaking, philosophical aesthetics could no longer follow or interpret contemporary art, which, starting from the late nineteenth and throughout the twentieth centuries, came to be vanished, or became canonised as modern, postmodern, or contemporary art. In the British and American context, philosophers such as William E. Kennick ${ }^{3}$, J. A. Passmore, ${ }^{4}$ and Morris Weitz ${ }^{5}$ problematised the status and priorities of "Continental aesthetics" or "general aesthetics", advocating a Wittgenstein-oriented conceptual analysis of aesthetics as understanding and explaining the concepts of art and those of aesthetics. By contrast, in the context of German critical philosophy, Theodor W. Adorno, in his Aesthetic Theory, posed the most sceptical question facing the dramatic shifts of modern art: 'It is self-evident that nothing concerning art is self-evident anymore, neither in it nor in its relation to the whole (zum Ganzen), not even its right to exist'. ${ }^{6}$ In his historicisation of Western aesthetics, the Croatian and Yugoslav theorist of aesthetics Danko Grlić interpreted German nineteenthcentury aesthetics under the heading of the Hegelian 'death of the aesthetic', and the aesthetic of the incipient twentieth century under the heading of 'beyond aesthetics' ${ }^{8}$

Grlićs analysis of late modernist art confronts us with the fact that modern aesthetics was unable to follow the fundamental changes of 1960s art and accept the necessity of revising aesthetic theory in a changed world, where old concepts (art, artwork, artistic practice) were gaining new meanings or losing their conventional functions. This was not about the 'suicide of art', but a fundamental change in the concept, methodology, and effects of the practice of art in relation to its traditions and bourgeois society. This was the shift that Morris Weitz encapsulated in his description of art as an 'open concept'. Roughly speaking, a shift occurred from the Picassoan poetics (his Guernica from 1937) to the Duchampian concept of artistic "intervention" by means of objects (his readymade In Advance of the Broken Arm from 1915). This shift in the 'object of study' also entailed a revision of aesthetic thought in relation to contemporary philosophies and turns from philosophy to theory and theorisation within the plural field of the humanities. 
A new philosophical or theoretical platform was necessary, that is, new platforms outside philosophical aesthetics in the field of artistic practices, or, from the other side, new platforms extending across structuralism and poststructuralism, cultural and media studies as an alternative to philosophical thinking about art. There ensued accelerated modifications in the domain of speaking and writing about art, a movement that replaced the great hierarchical platform of philosophy with different positionings and interpretative approaches.

The resulting multitude of unstable shifts may be roughly described with the following "narrative", only one among many other narratives that could be told about the arts in the late nineteenth through to the early twenty-first centuries.

Artistic micro- and macro-formations kept replacing one another at a fast pace, abrogating the notion of 'great styles' with concepts such as "tendencies", "phenomena", "movements", from realism, impressionism, symbolism, secession, expressionism, to futurism, etc. For instance, the relationship between art and the new techno aesthetics at the Bauhaus and the relationship between art and the new revolutionary aesthetics at the art institutes of the Soviet avantgarde (GinHuK, Vkhutemas) led toward the establishment of an expansive emancipatory modernity. But, running in parallel with this upheaval in the arts, differences took place within philosophy and political theory in relation to aesthetics. I would point to the differences between Marxist concepts of socialist realism (György Lukács) and critical theory of modern culture and art (Theodor W. Adorno, Walter Benjamin). One could also highlight the polemic between fundamental ontology (Martin Heidegger) and modern reflective art history (Meyer Schapiro). There were confrontations between positions pertaining to the concept of the autonomy of art and especially painting (Clement Greenberg, Michael Fried) and minimal art (Donald Judd, Robert Morris, Rosalind E. Krauss). Also, paradoxical comparisons were made between anti-art (Dada, Neo-Dada, Fluxus, John Cage), and anti-philosophy (Friedrich Nietzsche, Ludwig Wittgenstein, Jacques Lacan, Jean-François Lyotard). Attention was also drawn to the approaches of analytic meta-aesthetics in the interpretation of Duchamp's readymades as legitimate works of art (Morris Weitz, Arthur C. Danto, George Dickie). Conceptual art developed its own idea of theory in art (Joseph Kosuth, Art \& Language, Group 143). The group of French authors gathered around the Tel Quel magazine, especially Philippe Sollers, established a materialist theory of theoretical writing. Later interpreters spoke about an "age of theory". Likewise important were "theoretical conflicts" between phenomenology (Roman Ingarden, Vladimir Jankélévitch, Ivan Focht) and structuralism (Claude Lévi-Strauss, Louis Althusser) as well as poststructuralism 
(the late Roland Barthes, Jacques Derrida, Jean François-Lyotard). A special interpretative demand emerged concerning the need to identify the multiplicity of different aesthetics or theories alternative to aesthetics (Julia Kristeva, Hélène Cixous, Friedrich Kittler, Jacques Rancière, Brian Massumi, Terry Smith, Boris Groys, Aleš Erjavec) in relation to "contemporary art" (feminist, activist, political, environmental, participatory, and appropriative art). It was especially provocative to take note of the new philosophical fundamentalism encapsulated in Alain Badiou's four concepts - "Art, Love, Politics, and Science" - and its relation with the construction of the "Philosophy, Love, Politics, Aesthetics" graph in the Swiss contemporary artist Thomas Hirschhorn's politicisation of participatory art. These and many other examples open the field of discussion and my risky theorisation!

One possible diagram such as the one below may serve to highlight the productions of differences, ruptures, and constructions of new potentialities in the re-examining of the relationship between aesthetic and art in relation to philosophy and theory.

\begin{tabular}{|l|l|}
\hline \multicolumn{2}{|c|}{ PHI LOSOPHICAL AESTHETICS } \\
\hline $\begin{array}{l}\text { Aesthetics (Baumgarten, Kant, } \\
\text { neo-Kantianism) }\end{array}$ & Interpretations of specialised sensualities \\
\hline Aesthetics qua philosophy of art & $\begin{array}{l}\text { Introduction of phenomena and concepts of art into the field } \\
\text { of philosophical discussion }\end{array}$ \\
\hline $\begin{array}{l}\text { Aesthetics as the history of the } \\
\text { philosophy of art (Hegel, Arthur } \\
\text { Danto) }\end{array}$ & $\begin{array}{l}\text { Philosophical interpretations of the "nature", functions, and } \\
\text { meaning of art history and discourses about art histories }\end{array}$ \\
\hline Meta-aesthetics" & $\begin{array}{l}\text { Critique of the "language" and concepts of aesthetics in } \\
\text { disciplinary terms }\end{array}$ \\
\hline Theory of art ${ }^{10}$ & $\begin{array}{l}\text { The positioning of "art theory" in between the philosophy } \\
\text { of art and differentiating theories and theorisations in the } \\
\text { open field of the humanities, including the critique of } \\
\text { philosophy and the humanities itself }\end{array}$ \\
\hline Theory in art & $\begin{array}{l}\text { The incomparable multiplicity of theories, sciences, } \\
\text { and philosophies of various origins and functions in the } \\
\text { "artworld's" field of interest }\end{array}$ \\
\hline gender aesthetics and theory & $\begin{array}{l}\text { The domains of various theories pertaining to a specific } \\
\text { contextual positioning and approach to the paradoxes, } \\
\text { deviations, rambling, replacements, subversions, } \\
\text { innovations, catastrophic impacts, and, above all, } \\
\text { permanent changes in the "nature", functions, and meaning } \\
\text { of art }\end{array}$ \\
\hline $\begin{array}{l}\text { Women's perspective on understanding aesthetics, that is, } \\
\text { theories of art; and gender naturalisation (LGBT, queer) of } \\
\text { aesthetic and theoretical discourses about art and culture }\end{array}$ \\
\hline
\end{tabular}




\begin{tabular}{|c|c|}
\hline $\begin{array}{l}\text { The death of aesthetics project } \\
\text { (Hegel, Arthur Danto })^{13}\end{array}$ & $\begin{array}{l}\text { Projects intended to complete aesthetics from the domains } \\
\text { of philosophy and the humanities, that is, from highly } \\
\text { specific theories of art, culture, and media }\end{array}$ \\
\hline The hybridisation of aesthetics & $\begin{array}{l}\text { Implementation of the politics of difference i.e. decentring } \\
\text { in the field of philosophical aesthetics, the philosophy and } \\
\text { theory of art }\end{array}$ \\
\hline $\begin{array}{l}\text { The decentring of Eurocentric } \\
\text { aesthetics }{ }^{14}\end{array}$ & $\begin{array}{l}\text { Basing an aesthetic discourse on theories from postcolonial } \\
\text { and de-colonial studies }\end{array}$ \\
\hline Rebooting aesthetics ${ }^{15}$ & $\begin{array}{l}\text { Imagining a new beginning or zero position for constructing } \\
\text { aesthetics as the multitude of theories and theorisations } \\
\text { about the sensuous, art, culture, nature/the world, } \\
\text { technology, human as well as post-human and non-human }\end{array}$ \\
\hline Performing theory ${ }^{16}$ as practice & $\begin{array}{l}\text { Redefining theory as a set of articulated autonomous bodies } \\
\text { knowledge into the processing of theoretical procedures } \\
\text { i.e. material practices - theory as an event of accession and } \\
\text { retreat in interpretation, not as positing an attained final } \\
\text { body of knowledge about anything }\end{array}$ \\
\hline The politics of aesthetics ${ }^{17}$ & $\begin{array}{l}\text { Approaching aesthetics as a "practice" within various } \\
\text { social dispositives - not the aestheticisation of politics, but } \\
\text { discussing politics in aesthetic terms as a social relation in } \\
\text { relation to sensuality, corporeality, individual and collective } \\
\text { experiences, understandings and beings in the world as } \\
\text { the active and interactive dispositive i.e. infrastructure of } \\
\text { human "forms of life" }\end{array}$ \\
\hline Aesthetic regimes ${ }^{18}$ & $\begin{array}{l}\text { The demand that the aesthetic (aesthetic event, aesthetic } \\
\text { experience, aesthetic understanding, aesthetic affect) } \\
\text { be viewed as a moment in a process - in the volatile } \\
\text { multiplicity of events pertaining to "forms of life", } \\
\text { incomparable and yet simultaneous }\end{array}$ \\
\hline Aesthetic "assemblages"19 & $\begin{array}{l}\text { Unstable and shifting aesthetic complexities amid the } \\
\text { continual expansion of the possibility for connecting and } \\
\text { restructuring various "events" from "various spheres" of } \\
\text { human and other forms of life }\end{array}$ \\
\hline Aesthetic revolutions ${ }^{20}$ & $\begin{array}{l}\text { The end of an order between what may be seen/heard and } \\
\text { what may be said, knowledge and action, activity and } \\
\text { passivity }\end{array}$ \\
\hline \multicolumn{2}{|r|}{ THEORETICAL PRACTICES } \\
\hline & CRITICAL HUMANITIES \\
\hline
\end{tabular}

In other words, the diagram above may be viewed in terms of the critical and transformative relationship between 'philosophical aesthetics' and 'theoretical practices' in relation to the open and flexible field of the humanities i.e. contexts, dispositives, and infrastructures of theorisations about art and discourses about art under various conditions and circumstances. Therefore, the diagram may be simplified as follows: 


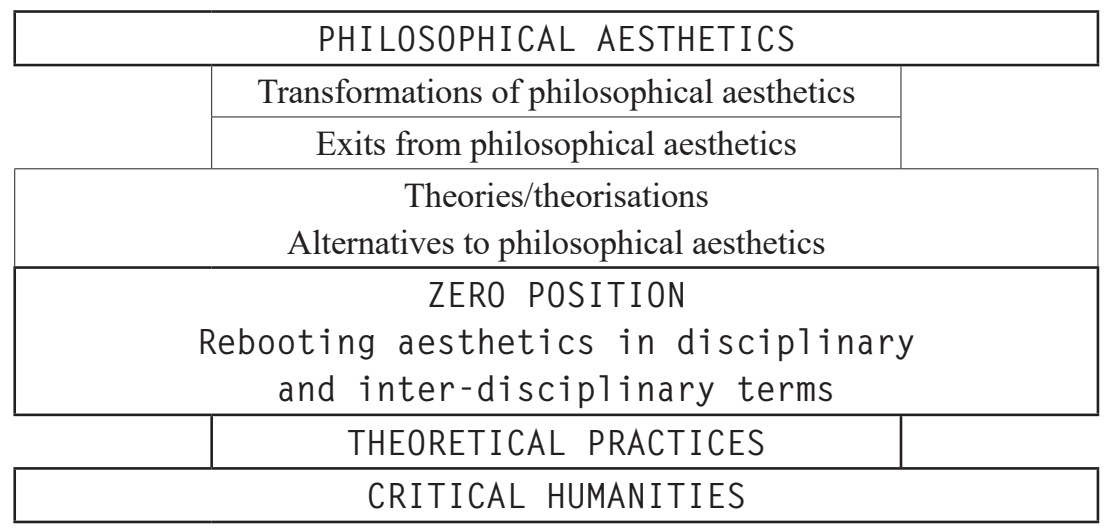

On the other hand, the whole story of the "aesthetic" and the "artistic" was moved from the discourse of aesthetics into the field of discourses developed in and around artistic practices and their positionings in the worlds of art, culture, and society. This concerns identifying the concept of "artistic theoretical practice". A diagrammatic representation yields the following set of relations:

\begin{tabular}{|l|l|}
\hline LETTERS, DIARIES $^{21}$ & Artists' private speaking/writing about art \\
\hline MANIFESTOES 22 & Public programme discourses \\
\hline THEORIES OF FORM ${ }^{23}$ & $\begin{array}{l}\text { Transforming poetic speech into a theory of procedures in } \\
\text { forming practices }\end{array}$ \\
\hline PRESENTED CONCEPTS 24 & $\begin{array}{l}\text { Conceptualising an art practice with examples or a } \\
\text { discourse that exemplifies the art practice itself, but without } \\
\text { theoretical aspirations }\end{array}$ \\
\hline THEORIES OF ARTISTS - I 25 & $\begin{array}{l}\text { Theorisations and pseudo-theorisations derived from an } \\
\text { immediate art practice }\end{array}$ \\
\hline THEORIES OF ARTISTS - II ${ }^{26}$ & $\begin{array}{l}\text { Theorisations of artists posited as theoretical platforms } \\
\text { independent from a concrete practice }\end{array}$ \\
\hline THEORIES OF ARTISTS - III 27 & $\begin{array}{l}\text { Theorisations of artists derived in relation to the open field } \\
\text { of the humanities or by entering the field of the humanities }\end{array}$ \\
\hline $\begin{array}{l}\text { DECONSTRUCTING AN } \\
\text { ARTIST'S THEORY28 }\end{array}$ & $\begin{array}{l}\text { Problematising or ironising an artist's theorisations by } \\
\text { means of hybrid discourses from popular, mass, i.e. media } \\
\text { culture }\end{array}$ \\
\hline $\begin{array}{l}\text { POLITICISATION OF } \\
\text { REFLECTIVE ART } \\
\text { PRACTICE29 }\end{array}$ & $\begin{array}{l}\text { Theorisation, reflection, self-reflection, interpretation as an } \\
\text { apparatus for intervening in the domain of the politics of art } \\
\text { or for intervening by means of art in the domain of politics }\end{array}$ \\
\hline
\end{tabular}

This brings me to an "image" of the surveyability of the unsurveyable, meaning the permanent complicating relations in various fields of the production of differences between "understanding and "non-understanding""; 
as well as influence, exchange, and domination, that is, deriving alternatives to current configurations of the power and disempowerment of theorising and philosophising in relation to an increasingly fluid art in the midst of antagonisms between reality and fiction. The relationship between art and aesthetics, that is, aesthetics and art, will therefore be presented with the following diagram, which delineates the domain of current research:

\begin{tabular}{|c|c|c|}
\hline $\begin{array}{c}\text { PHILOSOPHICAL } \\
\text { AESTHETICS }\end{array}$ & THEORY \\
\hline $\begin{array}{c}\text { Dialectics: } \\
\text { thesis-antithesis-synthesis }\end{array}$ & $\begin{array}{c}\text { Politics of difference: } \\
\text { comparability and } \\
\text { incomparability }\end{array}$ & $\begin{array}{c}\text { Dialectics of difference: } \\
\text { tactical turns }\end{array}$ \\
\hline $\begin{array}{c}\text { of the sensuous } \\
\text { of thinking about sensuality }\end{array}$ & $\begin{array}{c}\text { of the discourse of concepts- } \\
\text { sensualities }\end{array}$ & $\begin{array}{c}\text { of the dispositive of the } \\
\text { sensuous }\end{array}$ \\
\hline
\end{tabular}


Nicolai Hartmann, Aesthetics (Berlin: De Gruyter, 2017), 1.

William E. Kennick, "Does Traditional Aesthetics Rest on a Mistake?," in Contemporary Studies in Aesthetics, ed. Francis J., Coleman (New York: McGraw-Hill, 1968), 411-427.

J.A. Passmore, "The Dreariness of Aesthetics," in Contemporary Studies in Aesthetics, ed. Francis J., Coleman (New York: McGraw-Hill, 1968), 427-443.

Morris Weitz, "The Role of Theory in Aesthetics," in Contemporary Studies in Aesthetics, ed. Francis J., Coleman (New York: McGraw-Hill, 1968), 84-94.

Theodor W. Adorno, Aesthetic Theory. trans.R. Hullot-Kentor (Minneapolis: University of Minnesota Press, 1997), 1.

Danko Grlić, Estetika III - Smrt estetskog (Zagreb: Naprijed, 1978), 11-15.

Danko Grlić, Estetika IV - S onu stranu estetike (Zagreb: Naprijed, 1979), 11-21.

William R Elton, ed. Aesthetics and Language (Oxford: Basil Blackwell, 1954); Richard Shusterman, ed. Analytic Aesthetics (Oxford: Basil Blackwell, 1989).

Lawrence Alloway, Network: Art and the Complex Present (Ann Arbor, MI: UMI Research Press, 1984); Charles Harrison and Paul Wood, eds. Art in Theory 1900-2000: An Anthology of Changing Ideas. (Oxford, UK \& Cambridge, MA: Basil Blackwell, 2003).

Paul De Man, “The Resistance to Theory,” in Modern Criticism and Theory: A Reader, eds. David Lodge and Nigel Wood (London: Routledge, 2008), 432-445.

Lucy R. Lippard, From the Center: Feminist Essays on Women's Art (New York: Dutton, 1976); Teresa De Lauretis, Technologies of Gender: Essays on Theory, Film, and Fiction (Bloomington: Indiana University Press, 1987); Griselda Pollock, Vision \& Difference: Feminity, Feminism and the Histories of Art (London: Routledge, 1988); "Feminism and Traditional Aesthetics" (1990), Sara Ahmed, Queer Phenomenology: Orientations, Objects, Others (Durham, NC \& London: Duke University Press, 2006).

Arthur Danto, "The End of Art," in The Philosophical Disenfranchisement of Art, ed. Arthur Danto (New York: Columbia University Press, 1986), 81-115.

Terry Smith, Okwui Enwezor, and Nancy Condee, eds. Antinomies of Art and Culture: Modernity, Postmodernity, Contemporaneity (Durham, NC: Duke University Press, 2008); Achille Mbembe, "Necropolitics," Public Culture 15, no. 1 (Winter 2003): 11-40.

Wolfgang Welsch. Undoing Aesthetics (London: SAGE, 1997); Arnold Berleant, Re-Thinking Aesthetics (Aldershot, UK: Ashgate, 2005); Alain Badiou, Handbook of Inaesthetics (Stanford, CA: Stanford University Press, 2005).

Stuart Hall, "On Postmodernism and Articulation: An Interview with Stuart Hall," Journal of Communication Inquiry 10, no. 2 (June 1986): 45-60.

Gabriel Rockhill, Radical History \& the Politics of Art (New York: Columbia University Press, 2014).

Jacques Rancière, The Politics of Aesthetics (London: Continuum, 2004), 7-66.

Gilles Deleuze and Félix Guattari, Thousand Plateaus: Capitalism and Schizophrenia (Minneapolis \& London: University of Minnesota Press, 1987), 8; Brian Massumi, Semblance and Event: Activist Philosophy and the Occurrent Arts (Cambride, MA: The MIT Press, 2013).

Jacques Rancière, “The Aesthetic Revolution," in The Aesthetic Unconscious, (Cambridge: Polity, 2010), 21-30.; Aleš Erjavec, "Introduction," in Aesthetic Revolutions and Twentieth-century Avantgarde Movements, ed. Aleš Erjavec (Durham, NC \& London: Duke University Press, 2015), 2-3.

Ana H Suh, ed. Van Gogh's Letters: The Mind of the Artist in Paintings, Drawings, and Words, 1875-1890 (London: Black Dog, 2010); Tut Schlemmer, ed. The Letters and Diaries of Oskar Schlemmer (Evanston, IL: Northwestern University Press, 1990). 
André Breton, Manifestoes of Surrealism (Ann Arbor, MI: University of Michigan Press,1969); Umbro Appolonio, ed. Futurist Manifestos (London: The Viking Press, 1973).

Paul Klee, Pedagogical Sketchbook (London: Faber and Faber,1972); László Moholy-Nagy, Painting, Photography, Film (Cambridge, MA: The MIT Press,1973).

Michel Sanouillet and Elmer Person, eds. The Essential Writings of Marcel Duchamp (London: Thames and Hudson, 1975).

Kazimir Malevich, The Non-objective World (Cambridge, MA: The MIT Press, 1959).

Art\&Language: Texte zum Phänomen Kunst und Sprache (Köln: DuMont, 1972); John Cage, I-VI. Hanover, (NH: Wesleyan University Press, 1997).

Burgin, "The End of Art Theory," in The End of Art Theory: Criticism and Postmodernity, ed. Victor Burgin (Atlantic Highlands, NJ: Humanities Press International INC, 1987), 140-204; Lev Manovich, Software takes Command (London: Bloomsbury Academic, 2013).

Brian Wallis, ed. Blasted Allegories: An Anthology of Writings by Contemporary Artists (Cambridge, MA: The MIT Press, 1987).

Alexander Alberro, ed. Museum Hihglights: The Writings of Andrea Fraser (Cambridge, MA: The MIT Press, 2007); Liam Gillick, Industry and Intelligence: Contemporary Art since 1820 (New York: Columbia University Press, 2016); Hito Steyerl, Duty Free Art (London: Verso, 2017); Julie Enckell Julliard, ed. Thomas Hirschorn. MAPS (Vevey, Switzerland: Musée Jenisch, 2018). 
"Feminism and Traditional Aesthetics" (special issue). The Journal of Aesthetics and Art Criticism 48, no. 4. (1990).

Adorno, Theodor W. Aesthetic Theory. Translated by R. Hullot-Kentor. Minneapolis: University of Minnesota Press, 1997.

Ahmed, Sara. Queer Phenomenology: Orientations, Objects, Others. Durham, NC \& London: Duke University Press, 2006.

Alberro, Alexander, ed. Museum Hihglights: The Writings of Andrea Fraser. Cambridge, MA: The MIT Press, 2007.

Alloway, Lawrence. Network: Art and the Complex Present. Ann Arbor, MI: UMI Research Press, 1984.

Appolonio, Umbro, ed. Futurist Manifestos. London: The Viking Press, 1973.

Art\&Language: Texte zum Phänomen Kunst und Sprache. Köln: DuMont, 1972.

Badiou, Alain. Handbook of Inaesthetics. Stanford, CA: Stanford University Press, 2005.

Berleant, Arnold. Re-Thinking Aesthetics. Aldershot, UK: Ashgate, 2005.

Breton, André. Manifestoes of Surrealism. Ann Arbor, MI: University of Michigan Press, 1969.

Burgin, Victor. The End of Art Theory: Criticism and Postmodernity. Atlantic Highlands, NJ: Humanities Press International INC, 1987.

Cage, John. I-VI. Hanover, NH: Wesleyan University Press, 1997.

Coleman, Francis J., ed. Contemporary Studies in Aesthetics. New York: McGraw-Hill, 1968.

Danto, Arthur. The Philosophical Disenfranchisement of Art. New York: Columbia University Press, 1986.

De Lauretis, Teresa. Technologies of Gender: Essays on Theory, Film, and Fiction. Bloomington: Indiana University Press, 1987.

Deleuze, Gilles, and Félix Guattari. Thousand Plateaus: Capitalism and Schizophrenia. Minneapolis \& London: University of Minnesota Press, 1987.

Deleuze, Gilles. Foucault. Minneapolis \& London: University of Minnesota Press, 1988.

Elton, William R., ed. Aesthetics and Language. Oxford: Basil Blackwell, 1954.

Erjavec, Aleš, ed. Aesthetic Revolutions and Twentieth-century Avant-garde Movements. Durham, NC \& London: Duke University Press, 2015.

Gillick, Liam. Industry and Intelligence: Contemporary Art since 1820. New York: Columbia University Press, 2016.

Grlić, Danko. Estetika III - Smrt estetskog. Zagreb: Naprijed, 1978.

Grlić, Danko. Estetika IV - S onu stranu estetike. Zagreb: Naprijed, 1979.

Hall, Stuart. "On Postmodernism and Articulation: An Interview with Stuart Hall." Journal of Communication Inquiry 10, no. 2 (June 1986): 45-60.

Harrison, Charles, and Paul Wood, eds. Art in Theory 1900-2000: An Anthology of Changing Ideas. Oxford, UK \& Cambridge, MA: Basil Blackwell, 2003.

Hartmann, Nicolai. Aesthetics. Berlin: De Gruyter, 2017.

Julliard, Julie Enckell, ed. Thomas Hirschorn. MAPS. Vevey, Switzerland: Musée Jenisch, 2018.

Klee, Paul. Pedagogical Sketchbook. London: Faber and Faber,1972.

Lippard, Lucy R. From the Center: Feminist Essays on Women's Art. New York: Dutton, 1976.

Lodge, David, and Nigel Wood, eds. Modern Criticism and Theory: A Reader. London: Routledge, 2008 . 
Malevich, Kazimir. The Non-objective World. Cambridge, MA: The MIT Press.

Manovich, Lev. Software takes Command. London: Bloomsbury Academic, 2013.

Marks, Karl. Beda filozofije: odgovor na Filozofiju bede g. Prudona. Beograd: Kultura, 1946.

Massumi, Brian. Semblance and Event: Activist Philosophy and the Occurrent Arts. Cambride, MA: The MIT Press, 2013.

Mbembe, Achille. "Necropolitics.” Public Culture 15, no. 1 (Winter 2003): 11-40.

Moholy-Nagy, László. Painting, Photography, Film. Cambridge, MA: The MIT Press, 1973.

Pollock, Griselda. Vision \& Difference: Feminity, Feminism and the Histories of Art. London: Routledge, 1988.

Rancière, Jacques. The Politics of Aesthetics. London: Continuum, 2004.

Rancière, Jacques. "The Aesthetic Revolution." In The Aesthetic Unconscious, 21-30. Cambridge: Polity, 2010

Rockhill, Gabriel. Radical History \& the Politics of Art. New York: Columbia University Press, 2014.

Sanouillet, Michel, and Elmer Person, eds. The Essential Writings of Marcel Duchamp. London: Thames and Hudson, 1975.

Schlemmer, Tut, ed. The Letters and Diaries of Oskar Schlemmer. Evanston, IL: Northwestern University Press, 1990.

Shusterman, Richard, ed. Analytic Aesthetics. Oxford: Basil Blackwell, 1989.

Smith, Terry, Okwui Enwezor, and Nancy Condee, eds. Antinomies of Art and Culture: Modernity, Postmodernity, Contemporaneity. Durham, NC: Duke University Press, 2008.

Steyerl, Hito. Duty Free Art. London: Verso, 2017.

Suh, H. Ana, ed. Van Gogh's Letters: The Mind of the Artist in Paintings, Drawings, and Words, 1875-1890. London: Black Dog, 2010.

Tzara, Tristan. Seven Dada Manifestos; and, Lampisteries. Richmond: Alma Books, 2013.

Wallis, Brian, ed. Blasted Allegories: An Anthology of Writings by Contemporary Artists. Cambridge, MA: The MIT Press, 1987.

Welsch, Wolfgang. Undoing Aesthetics. London: SAGE, 1997. 


\section{GRADOVI KAO NAČINI STVARANJA SVETA}

\section{Curtis L. Carter}

Rad razmatra Tema "Načini stvaranja sveta" se pojavljuje u radovima filozofa poput Ernsta Kasirera (Ernst Cassirer) i Nelsona Gudmana (Nelson Goodman) (1906-1998.). Kasirer se ovom temom bavi u svom radu Jezik i mit (prevela Suzan Langer (Harper, 1946.)), a Gudman obrađuje "Načine stvaranja sveta" u svojoj istoimenoj knjizi (Hackett, 1978, 1981.). Oba filozofa navode umetnost kao ključan način za stvaranje sveta u svojoj funkciji različitih vrsta simbola. Prateći uvide Kasirera i Gudmana, "Načini stvaranja sveta" se ovde prvo razmatraju u odnosu na zamišljeni svet koji stvara uloge umetničkih dela koje se odnose na gradove. Primeri koji uključuju književna dela J. R. R. Tolkina, operu Kurta Veila i Bertolda Brehta, film kineskog umetnika Ksu Binga, njujorški Hadson Jards, najveći razvoj privatnih nekretnina u istoriji SAD-a do danas, se koriste kao primeri stvaranja sveta u umetnosti i razvoju gradova.

KLJUČNE REČI: STVARANJA SVETA, GRAD, TOLKIN, KURT VEIL / BERTOLD BREHT, KSU BING, HADSON JARDS, GUDMAN, KASIRER

\section{ZGRADE NAM GOVORE}

\section{Jale N. Erzen}

Polazeći od kritičkog pogleda na opšte arhitektonske i urbanističke strukture današnjice, ovaj rad će predstaviti zgrade koje se mogu porediti sa telom, tako što će njihov izraz i značenja koja imaju biti predstavljeni kao jezik forme koji utiče na ponašanje i psihologiju stanovnika u urbanim sredinama. Pozivajući se na arhitektonsku kritiku Žorža Bataja (George Bataille), tvrdi se da su fizički aspekti građevina značajni u onoj meri u kojoj prevazilaze materijalnost i vode ka simbolima i duhovnosti. Zgrade se posmatraju kao različite karakteristike i stavovi u zavisnosti od oblika. Arhitektura se takođe posmatra kao produkt rada i samim tim javna tvorevina koja svoje korene vuče iz korena ljudske kulture. Sve različite institucije su se istorijski razvijale iz različitih čula, postajući kulturna artikulacija i rezultirajući arhitekturama koja povezuje ljude u uživanju u zajedničkim interesovanjima. Dalje se tvrdi da urbani i prostorni oblici koji su zbunjujući u pogledu svojih granica i namena mogu izazvati konfuziju i negativne reakcije. Stoga je važno da jezik urbanih oblika bude pozitivan i jasan.

KLJUČNE REČI: ARHITEKTURA, TELO, JEZIK, FORMA, KULTURA

\section{ŠTA SE DOGODILO SA ESTETIKOM I UMETNOŠCU U PRETHODNIH 100 GODINA? PROTIVREČNOSTI I ANTAGONIZMI - RATOVI TEORIJA! \\ Miško Šuvaković}

Predmet ovog rada su dinamični i transformacioni odnosi između estetike i umetnosti od 1919. do 2019. godine. Prvi problem koji će se raspravljati biće odnos između umetnosti i politike u Bauhausu i umetničkih instituta Sovjetske avangarde. Zatim ću ukazati na razlike u marksističkim konceptima socijalističkog realizma i kritičkoj teoriji o modernoj kulturi i umetnosti. Analiziraću odnos između koncepta autonomije umetnosti, posebno slikarstva i minimalne umetnosti. Poređenje će biti izvedeno između anti-umetnosti (Dada, Neo-Dada) i anti-filozofije (Fridrih Niče, Ludvig Vitgenštajn, Žak Lakan). Osvrnuću se na pristupe od analitičke metaestetike do interpretacije Dišanovih redimejda, izvešću na osnovu toga teoriju umetnosti u konceptualnoj umetnosti. Posebna pažnja će se posvetiti "teorijskim sukobima" između fenomenologije i strukturalizma, kao i poststrukturalizma. Završiću svoju diskusiju identifikujući "estetski uslov” u odnosu na "savremenu umetnost" (feministička, aktivistička, politička, ekološka, participativna i aproprijacijska umetnost). 
Cilj moje diskusije je da istaknem karakter moderne i savremene estetike u odnosu na teoriju umetnosti, kroz dijagramsku refleksiju o binarnosti, razlikama i rekonstrukcijama dijalektike.

KLJUČNE REČI: UMENTIČKE ŠKOLE, MARKSIZAM, KRITIČKA TEORIJA, ANALITIČKA ESTETIKA, ISTORIJA UMETNOSTI, FENOMENOLOGIJA, STRUKTURALIZAM, POSTSTRUKTURALIZAM, SAVREMENA ESTETIKA I UMETNOST

\section{JEDNO ISLAMSKO NUMERIČKO TUMAČENJE SVETE SOFIJE U CARIGRADU}

\section{Vladimir Mako}

Ideje koje se odnose na estetičko mišljenje o arhitekturi tokom istorije su razvile brojna tumačenja o kulturnom i društvenom značaju građevina. Ova tumačenja su često oblikovana kao svet mogućeg postojanja posebnih značenja struktuiranih snagom čovekove imaginacije kojom dosežu nesvakidašnje nivoe kreativnog saznanja o tome šta arhitektura može suštinski odražavati.

U tom smislu rad istražuje jedan takav mogući svet značenja, predstavljenog u obliku numeričkog tumačenja arhitektonske strukture Svete Sofije u Carigradu. Pored svoje složene i hermenautičke prirode, analizirani dokument otkriva visoko prefinjeni nivo međuodnosa različitih kulturnih elemenata. Oni su povezani u celinu čija idealistička i poetska priroda, čini se da je zasnovana na kosmopolitanskom pristupu filozofiji, religiji, kao i ljudskoj sposobnosti razumevanja božanske suštine kreativnosti.

KLJUČNE REČI: ARHITEKTURA, ESTETIKA, BROJ, ISLAMSKA FILOZOFIJA, KOSMIČKA STRUKTURA

\section{MEDJUNARODNA ESTETIKA I KONGRESI NA TU TEMU}

\section{Aleš Erjavec}

Poslednjih decenija međunarodni kongresi na temu estetike su bili i ostaju najvidljiviji i najuticajniji estetski skupovi u svetu. Na tim kongresima učesnici jačaju svoju identifikaciju sa estetikom i istovremeno se odvajaju od nje: pokrivaju široku i nedefinisanu teritoriju zvanu "teorija". Održavajući se na različitim geografskim, a time i specifičnim kulturno-istorijskim lokalitetima, kongresi na temu estetike ne samo da okupljaju strane učesnike, već dovode i domaću publiku u kontakt sa globalnim autorima, temama, problemima i metodama. Teme, pitanja i metode se posmatraju kroz umetnost i filozofiju i pomažu da estetika postane relevantna teorijska aktivnost. To važi za neke zapažene nedavne događaje: uspon i pad postmodernizma; reintegracija bivše istočne Evrope u globalnu kulturu; i slična, ali takođe duboko drugačija transformacija estetike u Kini, gde je intenzivno prisutan novi preporod estetike, često sa kineskim bojama. To su, rekao bih, tri istorijska dogadjaja koja su se pojavila u estetici tokom poslednje tri decenije. Oni su i danas prisutni i tako ostaju presudni za razumevanje naše stvarnosti. Postoje i izuzeci koji dokazuju da su nove filozofske teorije estetike danas retke, ali nisu nemoguće; kao na primer teorija Žaka Ransijera. Ovo će biti neka od glavnih pitanja kojima će se baviti ovaj rad.

KLJUČNE REČI: MEDJUNARODNA ESTETIKA, MEDJUNARODNI KONGRESI O ESTETICI, TRANSFORMACIJA ESTETIKE, ŽAK RANSIJER, TEORIJE ESTETIKE 